\title{
Effect of Plyometric Hurdle Hops and Tuck Jump Training on Strength and Leg Muscle Power in Martial Arts Athletes at Kostrad Company-C Malang
}

\author{
Shidqi Hamdi Pratama Putera ${ }^{1}$, Hari Setijono ${ }^{2}$, Oce Wiriawan ${ }^{3}$ \\ ${ }^{1,2,3}$ Magister of Sport Education, Universitas Negeri Surabaya, Indonesia \\ shidqihamdi@gmail.com
}

\begin{abstract}
The purpose of this study was to analyze the effect of hurdle hops and tuck jump exercises on leg muscle strength and power, as well as the different effects of hurdle hops and tuck jump exercises on leg muscle strength and power. The research method used in this study is quantitative with quasi-experimental methods, with the design of this study using a non-randomize control group pretest and posttest design, with data analysis using ANOVA. The process of data retrieval is done by testing the leg muscle strength using a strength test tool that is a leg dynamometer and leg muscle power test with a jump md, during the pretest and posttest, then the data are analyzed using SPSS 22.0 series. The target of this study was martial arts athlete Kostrad Company-C with 30 members, divided into 3 groups with each group totaling 10 people, this research was conducted for 6 weeks. Paired sample strength test results and paired sample test of leg muscle power test that the significance level of each variable obtained sig 0,000 $<0.05$ thus there is a significant influence or difference between the pretest and posttest of the dependent variables of leg muscle strength and power, ANOVA test results on leg muscle strength and strength, showing strength, F: 12,191, sig 0,000, Power F: 4,778, sig 0.17, so it can be concluded that there are significant differences in the results of leg muscle strength and strength in three different groups, because sig <0.05. From the results of the post hoc multiple comparations ( $L S D)$ test of independent variables that have a significant influence on the increase in the dependent variable, it can be seen from the mean different results that the hurdle hops group gained 31,900 strength, power 155,367,00, meaning that the hurdle hops exercise was more influential. Based on the above analysis it can be concluded that there is an increase in leg muscle strength and power for each group, through the ANOVA test. Where hurdle hops exercises have a better effect than tuck jump exercises and the control group on leg muscle strength and power.
\end{abstract}

Keywords: Plyometric exercises; exercise hurdle hops; tuck jump.

\section{Introduction}

The development of sports at this time is not only carried out by certain circles, but it is well known that sports today have permeated the broad life and made a positive contribution to forming a healthy human and physical body. With the term sport is a systematic physical activity aimed at achieving achievement and health of the body, so that exercise when occupied will have a positive impact on the body. The sport of martial arts is currently in great demand by the world community, because martial arts is a legacy Indonesia's ancestral culture that deserves to be preserved, martial arts is a tactical martial, practically fast strong and can kill. But with the development of an increasingly advanced era, for the sake of introducing the sport of martial arts, throughout the world, a parent organization in Indonesia called IPSI was formed, while the parent organization of martial arts was named persi lat. Finally, from the birth of the parent organization, various national and international championships were created, in order to achieve the best achievements in the martial arts sport. 
Related to the categories competed in the regional, national or international martial arts championships which include the dueling, single, double and team categories. The competition category that was carried out in the martial arts competition was that featured 2 fighter from different angles, the two martial arts athletes competing used several kinds of training techniques that had been trained to be applied in the martial arts match including attacking, avoiding, falling, defending as well as using tactics in accordance with the pattern of steps and rules to get as many points as possible in 3 rounds, in a martial arts match many factors must be mastered including good biomotor skills to improve his performance. In order to support the performance in martial arts competition, athletes must have good leg muscle strength and power to support kick technique, training methods that can support aspects of physical condition and leg muscle strength that are plyometric hurdle hops and tuck jump training methods because these exercises have similarities kick technique moves in accordance with the anatomy of the body, more dominating the formation of leg muscle strength and power.

\section{Review of Literature}

According to Chu (1992) Plyometric training is a form of exercise that allows muscles to reach maximum strength in the shortest possible time, plyometric training combines strength and speed to produce strength and power that involves more muscle fibers to produce muscle spindles.

According to Radcliffe and Farentinos (1999: 13) anatomically hurdle hops and tuck jump exercises, the muscles involved are thigh flexion, involving sartorius, gracilis and illacus muscles, knee extension involves tensor fasciae latae muscles, vastus lateral, medillais, intermedius and rectus femoris. For martial arts athletes the match category, if you have a fast and strong kick will have a very big impact because when performing a kick attack technique that is shot it will not be easily slammed by the opponent, as well as accuracy of good kick technique movements without hindrance by blocking, using strength and power leg muscles then the effects are in the form of loud sounds produced from the opponent's body protector and can change the opponent's position to be unbalanced or the opponent to fall.

Refer to Chou, L. \& Link, N. (2011) entitled The Anatomy of Martial ARTS. and research from Delavier, F. \& Gundill, M. (2011) Mixed Martial arts Anatomy that martial arts athletes or martial arts when stealing points from opponents when during a game use kicks with the help of strenght and leg muscle power.

Kostrad Company-C branch is a martial arts branch that participated in regional and national championship events originating from Malang. Kostrad Company- $\mathrm{C}$ branches come from martial arts schools called self-defense, Based on direct observations that have been made by researchers with trainers Kostrad Company-C martial arts said it turned out with relatively the same technique when sparring (kick) is done in matches martial arts is still not good. This was proven during the competition, lack of strength and leg muscle power in martial arts athletes Kostrad Company-C Malang can cause weak kicks produced, and can cause kicks that are easily captured by opponents, so that when they get a good chance to shoot a kick to the body opponent's protector becomes unworkable. As researchers found during interviews with trainers it can be proven that the training methods given by trainers to athletes still use the old training methods and only rely on the experience of coaches who 
were once athletes without being supported by scientific literature in the formation of physical conditions. Therefore, the researcher wanted to conduct a study by giving plyometric hurdle hops and tuck jump training to the poor Kostrad Company-C martial arts athlete.

In this research, the sport of martial arts is suitable for using in the application of plyometric hurdle hops and tuck jump exercises because in the martial arts competition there are several kick techniques that require the use of strength and power when making these movements.

\section{Methodology}

The focus of the study was to find out the increased strength and power of the limbs. This research uses a quantitative approach. Quantitative method is a traditional method, because in this method has long been used to tradition as a method for research, as well as the method used is the method of experimentation. In this method of research implementation needed the appropriate research method of various research methods have a wide range, so that the research method to be used should be in accordance with what would be solved and problems with The goal that you want to achieve, with the experiment method of finding the causal relationship between two variables.

The technique of collecting data through the selection techniques of the informant, the male Martial Artsathletes aged 15-18 years. Data collection techniques are done with the treatment and documentation in the field.This research draft is widely divided into several phases, namely: (1) The research subject is taken from the population and then divided by using the sample random sampling, i.e. sampling of the population members is done simply. It is called simply because the sampling of the population of the populations is carried out randomly regardless of the strata in the population by voting (Sugiyono, 2012:82). Each group was conducted pretests i.e. experimental group as data $\left(\mathrm{T} 1_{1}\right),\left(\mathrm{T} 2_{2}\right)$ and control group as data $\left(\mathrm{T} 3_{3}\right)$; (2) The experimental group 1 was given a treatment (X1), namely hurdle hops, the experiment Group 2 was given treatment (X2), namely: Tuck jump; (3) The control group is given a conventional training program $(\mathrm{X})$, namely: training conducted according to the usual training programs.

Table 1. Research Design

\begin{tabular}{|l|l|l|}
\hline $\mathrm{T} 1_{1}$ & $\mathrm{X}_{1}$ & $\mathrm{~T} 2_{1}$ \\
\hline $\mathrm{T} 1_{2}$ & $\mathrm{X}_{2}$ & $\mathrm{~T} 2_{2}$ \\
\hline $\mathrm{T} 1_{3}$ & & $\mathrm{~T} 2_{3}$ \\
\hline
\end{tabular}

Source: Maksum (2012)

To provide meaning to the data in this research conducted analysis, the type of data to be collected in this study is the strength and power test of the leg muscles as well as the high radii of both types of exercise each group. After that the test results will be recorded and calculated based on the group and type of exercises applied, data analysis using descriptive statistic technique and in the analysis with the help of computer program SPSS (Statistical Program For Social Science) 22.0, Data normality test, homogeneity test and hypothesis test. 


\section{Discussion}

The following are the results of the study based on leg muscle strength tests using a leg dynamometer and power tests using the jump md test given to the experimental group I, experimental group II, and the control group. This chapter will describe the data description, the terms of hypothesis testing and the results of hypothesis testing. Description of the data to be presented in the form of data on the results of leg muscle strength tests and leg muscle power before (pretest) and after (posttest) were given treatment in each group which included: group I hurdle hops, group II tuck jump, and group III control. This research was conducted at 30 people of Kostrad Company-C Malang Martial Arts Athletes and divided into 3 groups, each group amounting to 10 people.

\section{a. Experimental group I exercises (Hurdle hops).}

In the hurdle hops exercise, the pretest and posttest data obtained both leg muscle strength and leg muscle power, the data include the mean, maximum value, minimum value and standard deviation.

\begin{tabular}{|c|c|c|c|c|c|}
\hline & & & & & \\
\hline & $\mathrm{N}$ & Mean & Std. Deviation & Minimum & Maximum \\
\hline PRETEST STRENGTH & 10 & 130.60 & 26.592 & 90 & 165 \\
\hline POSTESTSTRENGTH & 10 & 162.50 & 22.486 & 125 & 190 \\
\hline PRETEST POWER & 10 & 436.6540 & 152.12220 & 211.02 & 786.73 \\
\hline POSTEST POWER & 10 & 592.0210 & 160.05977 & 448.45 & 995.15 \\
\hline
\end{tabular}

Based on the results of the data obtained, it can be seen that the results of hurdle hops group training have increased the average strength and strength of leg muscles. This can be seen from the pretest and posttest data of leg muscle strength which was originally $130.60 \mathrm{~kg}$ increased to $162.50 \mathrm{~kg}$, while the pretest and posttest power of leg muscles which were originally 436.65 Joules to 592.02 Joules.

\section{b. Experimental group II exercises (Tuck Jump)}

In the tuck jump exercise obtained pretest and posttest data both leg muscle strength and leg muscle power. The data includes the mean, maximum value, minimum value and standard deviation.

\begin{tabular}{|l|r|r|r|r|r|}
\hline & N & \multicolumn{1}{|c|}{ Mean } & Std. Deviation & Minimum & Maximum \\
\hline PRETEST STRENGTH & 10 & 115.60 & 34.245 & 60 & 166 \\
POSTEST STRENGTH & 10 & 130.60 & 25.526 & 98 & 175 \\
PRETEST POWER & 10 & 431.1080 & 90.32002 & 300.84 & 569.86 \\
POSTEST POWER & 10 & 530.2380 & 87.94283 & 405.79 & 688.48 \\
& & & & & \\
\hline
\end{tabular}

Based on the results of the data obtained in table above, it can be seen that the results of the tuck jump group training have increased the average yield of leg muscle strength and leg muscle power. this can be seen from the pretest and posttest data of the leg muscle strength which was originally $115.60 \mathrm{~kg}$ increased to $130.60 \mathrm{~kg}$ and the pretest and posttest power of the original leg muscles 431.08 Joules increased to 530.23 Joules.

\section{c. What Exercise Group Control}

In the control group, pretest and posttest data were obtained for both leg muscle strength and leg muscle power. The data includes the mean (average), themaximum value, the minimum value and the standard deviation. 


\begin{tabular}{|l|r|r|r|r|r|}
\hline & \multicolumn{1}{|c|}{ D } & \multicolumn{1}{c|}{ Mean } & Std. Deviation & Minimum & Maximum \\
\hline PRETEST STRENGTH & 10 & 106.80 & 13.637 & 89 & 128 \\
POSTEST STRENGTH & 10 & 117.00 & 13.606 & 95 & 135 \\
PRETEST POWER & 10 & 365.2890 & 75.49799 & 236.08 & 482.40 \\
POSTEST POWER & 10 & 438.4640 & 64.25645 & 358.97 & 567.69 \\
& & & & & \\
\hline
\end{tabular}

Based on the results of the data obtained in the table, it can be seen that the results of the control group have increased the average yield of leg muscle strength and leg muscle power. This can be seen from the pretest and posttest data of the original leg muscle strength of $106.80 \mathrm{~kg}$ increasing to $117.00 \mathrm{~kg}$ and the pretest and posttest power of the original leg muscles 365.28 Joules to 438.46 Joules.

\section{Hypothesis Test Terms}

After describing the research data, the next step before testing the hypothesis is to test the normality and homogeneity tests. The aim is to find out whether the data is normally distributed and homogeneous.

\section{a. Normality Test}

Normality test conducted in this study using Kolmogorof Smirnov, if the p-value is greater than 0.05 , then the data are declared normally distributed. The data tested included research data on the increase in leg muscle strength and power from the hurdle hops (K1) group, the tuck jump (K2) exercise group data, and the control group.

\begin{tabular}{|l|c|c|c|c|c|c|}
\hline \multirow{4}{*}{} & \multicolumn{6}{|c|}{ Metode Latihan Plyometric Strength } \\
\cline { 2 - 7 } & \multicolumn{2}{|c|}{ Hurdle Hops } & \multicolumn{2}{c|}{ Tuck Jump } & \multicolumn{2}{c|}{ Kontrol } \\
\cline { 2 - 7 } & Pretest & Destest & Pretest & Restest & Pretest & Restest \\
\hline Sig & .200 & .200 & .074 & .200 & .200 & .200 \\
\hline Ket & $\mathrm{P}>0.05$ & $\mathrm{P}>0.05$ & $\mathrm{P}>0.05$ & $\mathrm{P}>0.05$ & $\mathrm{P}>0.05$ & $\mathrm{P}>0.05$ \\
\hline Status & Normal & Normal & Normal & Normal & Normal & Normal \\
\hline
\end{tabular}

\begin{tabular}{|l|c|c|c|c|c|c|}
\hline \multirow{4}{*}{} & \multicolumn{6}{|c|}{ Metode Latihan Plyometric Power } \\
\cline { 2 - 7 } & \multicolumn{2}{|c|}{ Hurdle Hops } & \multicolumn{2}{c|}{ Tuck Jump } & \multicolumn{2}{c|}{ Kontrol } \\
\cline { 2 - 7 } & Pretest & Restest & Pretest & Restest & Pretest & Pestest \\
\hline Sig & .200 & .122 & .200 & .200 & .200 & .200 \\
\hline Ket & $\mathrm{P}>0.05$ & $\mathrm{P}>0.05$ & $\mathrm{P}>0.05$ & $\mathrm{P}>0.05$ & $\mathrm{P}>0.05$ & $\mathrm{P}>0.05$ \\
\hline Status & Normal & Normal & Normal & Normal & Normal & Normal \\
\hline
\end{tabular}

Based on the data in table 4.4 above, it can be concluded that the normality test in the study data is an increase in leg muscle strength obtained from the hurdle hops (K1) exercise group. All significant values are greater than the $\mathrm{p}$-value 0.05 , so the data are normally distributed, the tuck exercise group jump (K2) obtained all significant values greater than pvalue 0.05 , then the data were normally distributed, the control group (K3) obtained all significant values greater than p-value 0.05 , then the data were normally distributed.

While from table 4.5 the normality test results in the study data increase in leg muscle strength from the hurdle hops training group (K1) obtained a significance value of all greater than p-value 0.05 , then the data were normally distributed, the tuck jump exercise group obtained a significant value of all greater from p-value 0.05 , then the data were normally distributed and the control group (K3) obtained significantly all greater than the p-value 0.05 , then the data were normally distributed. 


\section{b. Homogenity Test}

Homogeneity testing in this study was conducted on mean different data from each group using Lavene Test in the SPSS program. If the statistical value is upper 0.05 , the data hasa homogeneous variant.

\begin{tabular}{|l|c|c|c|c|}
\hline \multicolumn{5}{|c|}{ Levene's Test Of Equality Of Error } \\
& $\begin{array}{l}\text { Variances" strength } \\
\text { Statistic }\end{array}$ & $\mathrm{df1}$ & $\mathrm{df} 2$ & Sig \\
\hline & 1.136 & 2 & 27 & .336 \\
\hline $\begin{array}{l}\text { Base On } \\
\text { Mean }\end{array}$ & .804 & 2 & 27 & .458 \\
\hline $\begin{array}{l}\text { Base On } \\
\text { Median }\end{array}$ & & & & \\
\hline $\begin{array}{l}\text { Base On } \\
\text { Median } \\
\text { And With } \\
\text { Adiustes } \\
\text { Df }\end{array}$ & .804 & 2 & 21.994 & .460 \\
\hline $\begin{array}{l}\text { Base } \\
\text { Ontrimed } \\
\text { Mean }\end{array}$ & 1.197 & 2 & 27 & .318 \\
\hline
\end{tabular}

\begin{tabular}{|l|c|c|c|c|}
\hline \multicolumn{5}{|c|}{ Levene's Test Of Equality Of Error Variances" } \\
power
\end{tabular}

if seen from the results of the data in the table above shows that the significant value of all data is more than 0.05 , it can be concluded that the data are homogeneous. after knowing that the data generated are normally distributed and homogeneous, the research data is feasible to be used in further analysis.

\section{c. Hypotesis Test}

Testing different hypotheses the dependent variable is in paired samples using t-test analysis which in SPSS is called paired t-test. While testing the hypothesis of different is dependent on variables between groups using analysis of variance.

1. Difference Test Result for Paired Sample

To find out more clearly about the results of the t-test carried out in each group, 


\begin{tabular}{|c|c|c|c|c|}
\hline \multicolumn{5}{|c|}{ Paired Sampel Test strength } \\
\hline \multicolumn{2}{|c|}{} & Mean & $\mathrm{t}$ & Sig. (2tailed \\
\hline $\mathrm{K} 1$ & $\begin{array}{c}\text { Postest strenght } \\
\text { Pretest Strenght }\end{array}$ & 31.900 & 10.550 & .000 \\
\hline $\mathrm{K} 2$ & $\begin{array}{c}\text { Postest Strenght } \\
\text { Pretest Strenght }\end{array}$ & 15.000 & 3.631 & .005 \\
\hline $\mathrm{K} 3$ & $\begin{array}{c}\text { Postest Strenght } \\
\text { Pretest Strenght }\end{array}$ & 10.200 & 5.220 & .001 \\
\hline
\end{tabular}

\begin{tabular}{|c|c|c|c|c|}
\hline \multicolumn{5}{|c|}{ Paired Sampel Test power } \\
\hline \multicolumn{2}{|c|}{} & Mean & $\mathrm{t}$ & Sig. (2tailed) \\
\hline $\mathrm{K} 1$ & $\begin{array}{l}\text { Postest Power } \\
\text { Pretest Power }\end{array}$ & 155.36700 & 10.033 & .000 \\
\hline $\mathrm{K} 2$ & $\begin{array}{l}\text { Postest Power } \\
\text { Pretest Power }\end{array}$ & 99.130000 & 7.509 & .000 \\
\hline $\mathrm{K} 3$ & $\begin{array}{l}\text { Postest Power } \\
\text { Pretest Power }\end{array}$ & 73.17500 & 5.175 & .001 \\
\hline
\end{tabular}

Based on the two tables above, it shows that the significance level of each variable is obtained sig $<0.05$ thus there is a significant influence or difference between the pretest and posttest of each dependent variable (leg muscle strength and leg muscle power) both in the group experiment I, experimental group II, and experimental group III. So it can be concluded that there are differences after being given a hurdle hops training program, tuck jump training and in the control group.

2. Anova Test Result

In conducting the different tests, the data tested was the mean different of the three groups tested together. Different test in this study was carried out with the Anova test $(\mathrm{F})$ and the result was to find out whether or not there were differences in the results of the mean different in each group simultaneously

\begin{tabular}{|c|c|c|}
\hline VARIABEL & F & Siq \\
\hline STRENGHT & 12.191 & .000 \\
\hline POWER & 4.778 & .017 \\
\hline
\end{tabular}

Based on the results in the above table, it shows that the significant value of the Anova Test on leg muscle strength and power is sig $<0.05$. So it can be concluded that there are significant differences in the results of leg muscle strength and leg muscle power in three different groups.

Therefore, with differences in influence between groups, data analysis can be continued by using a post hoc multiple comporations test using Least Significant Difference (LSD) analysis in the SPSS 22.0 series program which aims to find out which independent variables significantly influence the increase in variables bound.

\begin{tabular}{|c|c|c|c|c|c|}
\hline \multirow{2}{*}{ VARIABEL } & \multirow[t]{2}{*}{ (I) } & \multirow[t]{2}{*}{$(\mathrm{J})$} & \multirow[t]{2}{*}{ Sig } & \multicolumn{2}{|c|}{$95 \%$ Confidence Interval } \\
\hline & & & & Lower bound & $\begin{array}{l}\text { Upper } \\
\text { bound }\end{array}$ \\
\hline \multirow{6}{*}{ Strenght } & \multirow[t]{2}{*}{ hurdle hops } & tuck jump & .001 & 7.72 & 26.08 \\
\hline & & kentrol & .000 & 12.52 & 30.88 \\
\hline & \multirow[t]{2}{*}{ tuckjump } & hurdle hops & .001 & -26.08 & -7.72 \\
\hline & & kentrol & .293 & -4.38 & 13.98 \\
\hline & \multirow{2}{*}{ kontrol } & hurdle hops & .000 & -30.88 & -12.52 \\
\hline & & tuckjump & .293 & -13.98 & 4.38 \\
\hline \multirow{6}{*}{ Power } & \multirow[t]{2}{*}{ hurdle hops } & tuck jump & .010 & 14.7225 & 97.7515 \\
\hline & & kentrol & .000 & 40.6775 & 123.7065 \\
\hline & \multirow[t]{2}{*}{ tuck jump } & hurdle hops & .010 & -97.7515 & -14.7225 \\
\hline & & kontrol & .210 & -15.5595 & 67.4695 \\
\hline & \multirow[t]{2}{*}{ kontrol } & hurdle hops & .000 & -123.7065 & -40.6775 \\
\hline & & tuck jump & .210 & -67.4695 & 15.5595 \\
\hline
\end{tabular}


Based on above shows that there are significant differences in the mean difference between the hurdle hops group and the tuck jump group and the control group both in the strength and leg muscle power variables. Based on these results it can be concluded that hurdle hops exercises have more effect on leg muscle strength and power compared to tuck jump and control groups.

\section{Conclusion}

Based on the results of the training and the mean test stated that the hurdle hops training gives better results compared to the provision of tuck jump training on leg muscle strength and leg muscle power in the Martial arts Athlete Kostrad Branch C Kompi Malang. This can be seen and analyzed from the process of hurdle hops exercises carried out by the process of jumping over the goal which is arranged parallel to repeatedly and holding the weight of the body that is resting on the limbs and hurdle hops training results in better functional adaptation of muscles and muscle coordination, while tuck jump training the movements are a little easier because there are no obstacles to block when jumping. From the results of a significant test using the posthoc test stated that there is a significant difference in the effect of the results of hurdle hops and tuck jump training on leg muscle strength and leg muscle power in Martial Arts Athlete Kostrad Company-C Malang.This is in line with the results of research conducted by Miller (2007: 145) that with a training devoted to increasing strength and power, when using plyometric exercises contribute to improving performance by increasing strength and power together with awareness of motion. In line with the results of Milic's research, (2008) that plyometric can contribute to increased speed, jumping and jumping, strength and power of leg muscles. Therefore the hurdle hops group is better than the tuck jump group and the control group, because the hurdle hops movement jumps forward or forward while the tuck jump movement only performs vertical upward movements by analyzing biomechanical motion and thus that is a major influence on the difference between the hurdle hops group with the tuck jump and control.

\section{References}

Bompa. 2009. Theory and Methodology of training. United States.Box terhadapPower Otot Tungkai. Unnes jurnal of sport sciences.

Chelly, M.S., Ghenem, M.A., Abid,K., Hermassi, S., Tabka,Z., and Shephard. R.J.2010. "Effects of in-Season Short - Term Plyometric Training Program on Leg Power, Jump -and Sprint performance of Soccer Players". Journal of Strength and Conditioning Research..

Chou, L. \& Link, N. 2011. The Anatomy of Martial ARTS. Ulysses Pres.

Chu, D. A. 1992. Jumping into plyometrics (second edition). California: leisure.Dallas:Human Kinetics.

Chu, Donald. A., and Myer G.D. 2013. Plyometric. United State Of AmericaHuman Kinetics.

Dar, A.A., Jhon, B.B., Chat, S.A dkk. 2016. Effect Of Plyometric Exercise On Horizontal Jump Performance. Journal of Physical E ducation, Sports and Health.

Dario F., Cappa \& David, G.B.(2011). Training Specificity Of Hurdle VS Countermovement Jump Training, Vol. 25 No. 10. 
Dario F., Cappa \& David, G.B. 2013 Neuromuscular Charateristic Of Drop and Hurdle Jumps With Different Types of Landings.

Delavier, F.\&Gundill, M. 2011. Mixed Martial arts Anatomy. Ulysses Pres.

Fransisco, F., Alessio, V., \& Stefania, C., 2018. Effect of Plyometric Training Program on Speed and Exsplosive Strength of Low Limbs in Young Athletes. Journal Of Education and Sport.

Kerim, S. 2016.Effects of 6-Week Plyometric Training on Vertical Jump Performance and Muscle Activation of Lower Extremity Muscle. The Sport Journal.

Manske, R. 2015. Current Concepts of Plyometric Exercise," The International Journal of Sport Physical Therapy. 